\title{
Research Journal of Pharmaceutical, Biological and Chemical Sciences
}

\section{Isolation and Characterization of Plant Growth-Promoting Rhizobacteria from Trigonella foenum- graecum $L$ Rhizosphere and Evaluation of their Potential Substances Produced.}

\author{
Warda E Ashour ${ }^{1}$, Eman R Hamed ${ }^{1 *}$, Ahmed I El-Diwany ${ }^{1}$, Mahmoud A Swelim ${ }^{2}$, and \\ Abeer A Abd El Aty ${ }^{1}$. \\ ${ }^{1}$ Chemistry of Natural and Microbial Products Department, Pharmaceutical and Drug Industries Research Division, National \\ Research Center, Dokki-12311, Giza, Egypt. \\ ${ }^{2}$ Botany department, Faculty of science, Banha University.

\section{ABSTRACT}

The aim of this study was to isolate rhizobacterial strains (PGPR) that have the ability to produce phytohormones [Indol acetic acid, (IAA)], Hydrogen cyanide (HCN), Siderophore, Ammonia, Phosphate solubilization, chitinase enzyme activity and also have broad spectrum against phytpathogenic fungi. A total of thirty bacterial strains isolated from the rhizosphere of Trigonella foenum- graecum L. They are characterized according to their morphological characteristics. Twenty three bacterial isolates were found to have broad spectrum antifungal activities against pathogenic fungi, and found to be able to produce hydrogen cyanide ranging from dark brown to faint brown. Only one strain identified as Bacillus cereus KU058893 was able to produce dark brown, which indicated that it produced high amount of HCN and Brevundimonus diminuta KT277492 gave brown colour which indicate moderate production of HCN. Also, twenty bacterial isolates out of thirty with percentage $66.67 \%$ were found to be siderphore producers. Ten isolates with a percentage $33.3 \%$ were able to produce IAA in the absence of tryptophan while $66.7 \%$ were unable to produce IAA in the absence of tryptophan, B. diminuta KT277492 was the most active producer strain of IAA $(24.912 \pm 0.045 \mu \mathrm{g} / \mathrm{ml})$. While $B$. cereus produced $15.034 \pm 0.0707 \mu \mathrm{g} / \mathrm{ml}$. While in the presence of tryptophan at $0.1 \%$ concentration, $B$. diminuta $\mathrm{KT} 277492$ was also the most active producer of IAA $(31.723 \pm 0.0059 \mu \mathrm{g} / \mathrm{ml})$. While $B$. cereus KU058893 produced $22.2 \pm 0.046 \mu \mathrm{g} / \mathrm{ml}$. while $80 \%$ of the bacterial isolates were able to produce ammonia, 6 isolates represented $20 \%$ didn't produce ammonia. We found that about eleven isolates were able to hydrolyze Phosphate which represents about $36.667 \%$ of the total isolates, nineteen isolates were not able to hydrolysis phosphate with percentage $63.333 \%$. B. diminuta KT277492 showed the highest chitinase enzyme activity $95 \mathrm{IUL}^{-1}$ on the (NB+ chitin) medium.

Keywords: Chitinase enzyme, Bacillus cereus KU058893, Brevundimonus diminuta KT277492, Plant growth-promoting bacteria, Trigonella foenum, . 


\section{INTRODUCTION}

Plant pathogenic fungi cause reduces in crop yield. To overcome the fungal plant infection and increase the crop yield was by using chemical fertilizers and pesticides. On the other hand use of chemical fertilizers and pesticidesincreases environmental pollution, health hazards and sometimes induces Phytotoxicity (Shehata et al 2012).We can say they have bad effect to the entire ecosystem. So scientists had to search for new tools to overcome this problem. In the recent year, scientists gave great attention to the beneficial microbes that habitat the rhizosphere. The rhizosphere is the narrow zone of soil which is rich in nutrients due to the accumulation of a variety of plant exudates, such as amino acids and sugars, providing a rich source of energy and nutrients for bacteria (Gray and Smith, 2005, Beneduzi et al., 2012 and Hamed et al 2015). Plant-associated bacteria can be classified into beneficial, deleterious and neutral groups on the basis of theireffects on plant growth (Dobbelaere et al., 2003). Beneficialfree-living soil bacteria are usually referred to as plant growth-promoting rhizobacteria (Kloepper et al., 1989). Lwin et al., (2012) stated that plant growth promoting rhizobacteria (PGPR) are bacteria that have the ability to colonize plants root hairs and increase plant growth and yield (Davis, 1995). Datta et al., (2011) stated that, Plant growth promoting rhizobacteria (PGPR) constitute approximately 2-5\% of the total rhizomicrobial population (Kloepper et al. 1980). Beneduzi et al. (2012) showed that, PGPR works indirectly or directly. The direct promotion of plant growth by PGPR is either by providing the plant with a compound that the bacterium synthesize, for example phytohormones or by facilitating the uptake of certain nutrients from the soil (Glick, 1995) and fixation of atmospheric nitrogen, solublization of minerals such as phosphorus, production of siderophores, and synthesis of plant growth hormones i.e. Indole-3- acetic acid (IAA), gibberellic acid, cytokinins, and ethylene (Nelson. 2004 andKumar, et al., 2012).The indirect promotion of plant growth occurs when PGPR decrease or prevent the deleterious effects of one or more phytopathogenic organisms(Anjum et al., 2007 and Lwin et al., 2012). This can happen through the production ofantibiotics, lytic enzymes, hydrogen cyanide, catalase and siderophore or through competition for nutrients and space canimprove significantly plant health and promote growth, as evidencedby increases in seedling emergence, vigor, and yield (Khan, 2006). Chitinase may be applied as insecticides and fungicides to control pests and fungal pathogens of plants respectively (Wang, et al 2006). Various species of bacteria have been recorded as plant growth promoting rhizobacteria that promote and enhance plant growth such as Pseudomonas, Azospirillum, Azotobacter, Klebsiella, Entrobacter, Alcaligenes, Arthrobacter, Bacillus and Serratia (Lwin, et al. 2012).

Ashrafuzzaman et al., (2009) reported that, bio-fertilizers such as microbial inoculantspromote plant growth, productivity and increase the nutrient status of the host plant have internationally been accepted as an alternativesource of chemical fertilizers (Vessey, 2003). Significant increases in crop yieldshave been reported by applying PGPR microbial inoculants (Salamone, 2000). So, keeping all this in view, the present study was carried out to isolatethe mostactive plant growth promoting rhizobacteria trains from the rhizospheric soils of Trigonella foenum-graecum-L. The objectives of this research were to screen potential PGPR from Trigonella foenum rhizosphere which produce phytohormones, Hydrogen cyanide (HCN), Siderophore, Ammonia, Phosphate solubilization and extracellular chitinase.

\section{MATERIALS AND METHODS}

\section{Source of samples}

The rhizospheres samples and plant roots were collected from the green house of Ministry of Agriculture, Giza, Egypt. The collected samples were brought to the laboratory in clean plastic bags.

\section{Isolation of PGPR from rhizosphere}

Five grams of rhizosphere soil were taken into a $100 \mathrm{~mL}$ of conical flask, and $45 \mathrm{~mL}$ of sterile distilled water was added to it. The flask was shaken for $10 \mathrm{~min}$ on a rotary shaker. One milliliter of suspension was added to $5 \mathrm{~mL}$ vial and shaken for $1 \mathrm{~min}$. An aliquot $(0.1 \mathrm{~mL})$ of this suspension was spread on the plates of Luria Bartany (LB) agar medium. Plates were incubated for 3 days at $28^{\circ} \mathrm{C}$ to observe the colonies of bacteria. Bacterial colonies were streaked to other LB agar plates and the plates were incubated at $28^{\circ} \mathrm{C}$ for 3 days. Well isolated single colony was picked up and re-streaked to fresh LB agar plate and incubated under the same condition. (Ashrafuzzaman et al., 2009). 


\section{Isolation from the root sample}

The root sample $(1 \mathrm{~g})$ was taken and surface sterilized with $0.2 \% \mathrm{HgCl}_{2}$ for $3-5$ minutes and then washed thoroughly (10 times) with sterilize distilled water to make it free from $\mathrm{HgCl}_{2}$. The samples were then used for isolation of rhizobacteria on LB agar by using modified replica plating technique. (Abou-Zeid et al., 2004, Abou-Zeid et al., 2008 and Kaushal et al., 2011).

\section{Characterization of bacterial isolates}

Morphological characteristics (shape, color and odor) of the colony of each isolate were examined on nutrient agar plates. (Ashrafuzzaman et al., 2009).

\section{Morphological characteristics}

The suspected organisms were subjected to Gram's staining (Vincent, 1970). The bacteria which retained the primary stain called gram ${ }^{+}$ve, while those that lost the crystal violet and counter stained by safranin were referred as gram $^{- \text {ve. }}$

\section{Antagonistic effects of isolated bacteria towards soil borne plant pathogen}

Isolated bacteria were tested toward soil borne plant pathogens; Fusarium solani, F. verticillioides and Rhizoctonia solani which were isolated previously in National Research Center. The test was carried out according to the method of (Varese et al., 1996). The pathogens were grown on Petri dishes containing Potato Dextrose Agar (Difco) Media. Colony of bacteria was placed on one side of the Petri dish and the pathogen disk placed on the other side. The Petri dishes were incubated at $25{ }^{\circ} \mathrm{C}$ for 7 days. The growth of mycelium was measured and compared to the control treatment (Budi and Nunang, 2012). The evaluation of bacterial growth is performed by measuring the diameter of the colony of the pathogen and the bacterial antagonist. The evaluation of inhibition by the tested bacterial strains was estimated by calculating the percentage of mycelia growth inhibition by using the following formula

$$
\%=(1-\mathrm{Cn} / \mathrm{Co}) \times 100 \text {. }
$$

$\mathrm{Cn}$ is the average of pathogen colonies diameter in the presence of antagonist and Co is the average diameter of control. (Bouziane et al., 2011).

\section{Screening of PGPR for multiple plant growth promoting activities}

\section{Detection of IAA}

\section{Culture growth conditions}

According to Kumar et al. (2012) Fifty milliliter of Nutrient broth (NB) containing $(00.0 \%$ and $0.1 \%$ )DLtryptophan was inoculated with $500 \mathrm{NI}$ of $24 \mathrm{~h}$ old bacterial cultures and incubated in refrigerated incubator Shaker at $30 \pm 0.1^{\circ} \mathrm{C}$ and $180 \mathrm{rpm}$ for $48 \mathrm{~h}$ in dark. The bacterial cultures were centrifuged at 10,000 rpm for $10 \mathrm{~min}$ at $4^{\circ} \mathrm{C}$. Estimation of indole-3-acetic acid (IAA) in the supernatants was done using colorimetric assay (Loper, et al. 1986; Ruci, et al., 2012). Appearance of pink color in test tubes indicated IAA production described by (Gordon and Weber, 1951).

\section{Production of Ammonia}

All the bacterial isolates were tested for the production of ammonia as described by (Cappuccino and Sherman, 1992). Overnight grown bacterial cultures were inoculated in $10 \mathrm{ml}$ peptone broth and incubated at $30 \pm 0.1^{\circ} \mathrm{C}$ for $48 \mathrm{~h}$ in Incubator shaker. After incubation $0.5 \mathrm{ml}$ of Nessler's reagent was added. The development of faint yellow $(+)$, deep yellow $(++)$ to dark brown color $(+++)$ indicated the production of ammonia. 


\section{HCN production}

According to Geetha, et al. (2014) Hydrogen cyanide (HCN) production was evaluated by streaking the bacterial isolates on King's B agar medium amended with glycine. Whatman No.1 filter paper soaked in picric acid $(0.05 \%$ solution in $2 \%$ sodium carbonate) was placed in the lid of each Petri plate. The plates were then sealed air-tight with Para-film and incubated at $30^{\circ} \mathrm{C}$ for $48 \mathrm{~h}$. A colour change of the filter paper from deep yellow to reddish-brown colour was considered as an indication of HCN production (Bakker and Schipperes, 1987).

\section{Siderophore production}

According to Sujatha and Ammani, (2013) Siderophore production was detected by adding $0.5 \mathrm{ml}$ of culture filtrate to $0.5 \mathrm{ml}$ of $2 \%$ aqueous $\mathrm{FeCl}_{3}$ for the appearance of orange or reddish brown colour which was positive indication of siderphore production.

\section{Identification of selected PGPR strains by sequencing of 16S rRNA gene}

The most two active strains were aerobically grown in Nutrient Broth (NB) for $24 \mathrm{~h}$ at 28C, and genomic DNA was extracted according to the method of (Higgins et al.,2007). The 16S rRNA gene of the selected bacteria was PCR amplified by using forward and reverse primers, fD1 (5'AGAGTTTGATCCTGGCTCAG$3^{\prime}$ ) and rP2 (5'- ACGGCTACCTTGTTACGACTT -3'), respectively (Weisburg et al., 1991). The nucleotide sequence of purified PCR products was analyzed at the Macrogen Service Center (Seoul, Korea). The derived DNA sequences were aligned with DNA sequences present in GenBank (http://www.ncbi.nlm.nih.gov/Blast).

\section{Effect of media component on chitinase enzyme production}

Five different broth media were screened for chitinase production by $B$. diminuta KT277492 and $B$. cereus KU058893 isolates. The first was Lauri bertaini broth (LB) $\left(\mathrm{gl}^{-1}\right)$ : tryptone, 10; yeast extract, 5.0; $\mathrm{NaCl}$, 5.0. King broth $(\mathrm{KB})\left(\mathrm{gl}^{-1}\right)$ : peptone, 20.0; dipotassium hydrogen phosphate, 1.5; magnesium sulphate heptahydrate 1.5. Nutrient broth (NB) $\left(\mathrm{gl}^{-1}\right)$ : yeast extract, 1.5; $\mathrm{NaCl} 5.0$; beef extract 1.5. Wheat bran media (WB) $\left(\mathrm{gl}^{-1}\right)$ : wheat bran, 60 and Nutrient broth medium supplemented with $1 \%$ chitin as substrate (Kuddus and Ahmad 2013).

\section{Assay of chitinase activity}

According to Sudhakar and Nagarajan (2011) Chitinase activity was determined by a dinitrosalicylic acid (DNS) method (Miller,1959) with some modification. This method works on the concentration of $N$-acetyl glucosamine (NAG), which is released as a result of enzymatic action (Ulhoa and peberdy 1991). The 2ml reaction mixture contained $0.5 \mathrm{ml}$ of $0.5 \%$ colloidal chitin in acetate buffer ( $\mathrm{pH} 5.5$ ), $0.5 \mathrm{ml}$ crude enzyme extract and $1 \mathrm{ml}$ distilled water. The well vortexed mixture was incubated in a water bath shaker at $40^{\circ} \mathrm{C}$ for 2 $\mathrm{h}$. The reaction was arrested by the addition of $3 \mathrm{ml}$ DNS reagent followed by heating at $100^{\circ} \mathrm{C}$ for 10 min with $40 \%$ Rochelle's salt solution. The colored solution was centrifuged at 10,000 rotations per minute for 5 min and the absorption of the appropriately diluted test sample was measured at $530 \mathrm{~nm}$ using UV spectrophotometer (UV-160 A, Shimadzu, Japan) along with substrate and enzyme blanks. Colloidal chitin was prepared by the modified method of (Roberts and Selitrenkoff, 1988). One unit (U) of the chitinase activity is defined as the amount of enzyme that is required to release $1 \mu \mathrm{mol}$ of $\mathrm{N}$-acetyl-d-glucosamine per minute from $0.5 \%$ of dry colloidal chitin solution under assay conditions.

\section{RESULTS AND DISCUSSION}

Thirty bacterial isolates were isolated, 17 bacterial isolates were isolated from the rhizosphere (Prhizo) with a percentage $56.67 \%$ and 13 bacterial isolates from the root (Proot) of the Trigonella foenumgraecum-L. with percentage $43.33 \%$. Colonies showing different morphological characteristics on the plates were selected for further characterization. A total 30 strains were isolated with different morphological characteristics and their PGPR characteristics were studied. 
Data in Table (1) show that, the isolated bacterial strains varied between smooth shiny, crinkled shiny surface and colours ranging between light yellow, off white, milky and creamy, one strain was mustard and one isolate was pink. All the isolates were odourless except 3 isolates had rotten egg odour. On contrast UmaMaheswari et al., (2013) studies proved thatMajority of the isolates appeared colourless, circular in form and with entire margin. Nine isolates were coloured such as yellow, orange and pink.Our resultsrevealed that, the isolated bacteria were both Gram positive with percentage $90 \%$ and Gram negative $10 \%$, and $80 \%$ were long rod and $20 \%$ cocci shape.Similar results were reviewed by UmaMaheswari et al., (2013) who isolated twenty five isolates, eighteen isolates were rod shaped with percentage $72 \%$ and other 7 with percentage $28 \%$ were coccalshaped .Gardner et al., (1982), Zinniel et al., (2002) studies showed that (41\%) of the bacterial isolates were gram-positive while the percentages of gram-negative was (42\%).

Table (1): Morphological characteristics of the isolates on nutrient agar

\begin{tabular}{|c|c|c|c|c|}
\hline Isolate & shape & Gram test & colour & odour \\
\hline Prhizo1 & short rod & -ve & Light yellow & odourless \\
\hline Prhizo2 & long rod sporulated & +ve & off white & odourless \\
\hline Prhizo3 & cocci & +ve & off white & odourless \\
\hline Prhizo4 & long rod & +ve & Light yellow & odourless \\
\hline Prhizo5 & long rod & +ve & off white & odourless \\
\hline Prhizo6 & cocci & + ve & off white & odourless \\
\hline Prhizo7 & cocci & +ve & Light yellow & odourless \\
\hline Prhizo8 & cocci & +ve & off white & odourless \\
\hline Prhizo9 & cocci & +ve & Pink & odourless \\
\hline Prhizo10 & long rod & +ve & Light yellow & Rotten egg \\
\hline Prhizo11 & long rod & +ve & off white & odourless \\
\hline Prhizo12 & long rod & +ve & off white & odourless \\
\hline Prhizo13 & long rod & +ve & mustard & odourless \\
\hline Prhizo14 & long rod & +ve & off white & odourless \\
\hline Prhizo15 & long rod & + ve & off white & odourless \\
\hline Prhizo16 & cocci & +ve & Light yellow & odourless \\
\hline Prhizo17 & cocci & -ve & off white & odourless \\
\hline Proot 18 & cocci & +ve & off white & odourless \\
\hline Proot 19 & long rod & +ve & Milky & odourless \\
\hline Proot 20 & short rod & +ve & off white & odourless \\
\hline Proot 21 & long rod & +ve & off white & odourless \\
\hline Proot 22 & long rod & +ve & Light yellow & odourless \\
\hline Proot 23 & long rod & +ve & off white & odourless \\
\hline Proot 24 & cocci & -ve & off white & odourless \\
\hline Proot 25 & long rod & +ve & yellow & Rotten egg \\
\hline Proot 26 & long rod & +ve & off white & odourless \\
\hline Proot 27 & cocci & +ve & off white & odourless \\
\hline Proot 28 & long rod & +ve & Light yellow & Rotten egg \\
\hline Proot 29 & long rod & +ve & off white & odourless \\
\hline Proot 30 & cocci & +ve & off white & odourless \\
\hline
\end{tabular}

Bacterial isolates from rhizosphere (Prhizo), bacterial isolates from the root (Proot)

\section{Antagonistic effects of isolated bacteria towards soil borne plant pathogen}

Thirty bacterial isolates were tested against 3 different pathogenic fungi; Fusarium solani, Rhizoctonia solani and F. verticillioides. Eleven isolates with a percentage $36.67 \%$ have been found to have broad spectrum antifungal activities against these pathogenic fungi. The antagonistic effect varied between the bacterial isolates as shown in Table (2) and Fig. (1). on the other hands Prhizo1which was identified as B. diminuta KT277492 showed high antagonistic activities against the three pathogenic fungi and burn the pathogen on the pathogenic inoculated disk with percentage 99\%, 90\% and 90\%.Sri and Nunang (2012) work revealed that the bacterial isolates Bacillus subtilis, Pseudomonas diminuta, Proteus penneri and Enterobacter hormaechei have theability to inhibit the growth of three tested phytopathogens Sclerotium sp., Rhizoctonia sp. and Ganoderma sp. The percentages of inhibition produced by Bacillus subtilis Pseudomonas diminuta was 79$80 \%$. 
Furthermore Prhizo'2' which is also identified as Bacillus cereus showed a very clear zone with $F$. solani, $R$. solani and $F$. verticillioides with inhibition zone percentage $50 \%, 45 \%$ and $55 \%$ respectively.

Sri and Nunang (2013) work proved that Bacillus cereus inhibited the growth of Sclerotium sp, Rhizoctonia sp. and Ganoderma sp. with percentage 59-90\%. While bacterial isolate Prhizo14 which isolated from the rhizosphere and Proot 20and Proot 18 which isolated from the root showed antagonistic effect against Rhizoctonia solani and $F$. verticillioides while they showed no activities against Fusarium solani. Moreover Prhizo17 which isolated from the rhizosphere and Proot 28 which isolated from the root showed antagonistic effect against Fusarium solani and F. verticillioides while it showed no antagonism against Rhizoctonia solani Furthermore Proot 23 and Proot 29 which isolated from the root showed antagonistic effect against Fusarium solani and Rhizoctonia solani while there were no activities against $F$. verticillioides.

Kabir et al. (2012) isolated 125 bacterial strains from rhizosphoric soil, only seven isolate were capable of inhibiting the phytopathogenic fungi Colletotrichum acutatum in vitro dual culture screening tecnique. They added that all the seven bacterial isolates produced inhibition zone more than $50 \%$ of $C$. acutatumon dual culture plates and The greatest inhibition ability of mycelia growth of the fungi was produced by isolate $A B 15(69.22 \%)$; moreover, $A B 05, A B 11, A B 12$, and $A B 17$ also produced more than $60 \%$ inhibition of the radial growth of $C$. acutatum.

Table (2): Percentage of antagonistic activity between the isolated bacterial strains against three pathogenic fungi

\begin{tabular}{|c|c|c|c|}
\hline \multirow[b]{2}{*}{ Bacterial isolate no. } & \multicolumn{3}{|c|}{ Pathogenic fungi } \\
\hline & \multirow[t]{2}{*}{ Fusarium solani } & \multirow[t]{2}{*}{$\begin{array}{c}\text { Rhizoctonia } \\
\text { solani }\end{array}$} & \multirow[t]{2}{*}{$\begin{array}{c}\text { Fusarium } \\
\text { verticillioides }\end{array}$} \\
\hline Rhizosphere & & & \\
\hline Prhizo $1^{*}$ & $99 \%$ & $90 \%$ & $90 \%$ \\
\hline Prhizo2** & $50 \%$ & $45 \%$ & $55 \%$ \\
\hline Prhizo3** & $30 \%$ & $27 \%$ & $33 \%$ \\
\hline Prhizo4 & $9 \%$ & 0 & 0 \\
\hline Prhizo5 & 0 & 0 & 0 \\
\hline Prhizo6 & $5 \%$ & 0 & $9 \%$ \\
\hline Prhizo7 & 0 & 0 & 0 \\
\hline Prhizo8 & $15 \%$ & $18 \%$ & $9 \%$ \\
\hline Prhizo9 & 0 & 0 & 0 \\
\hline Prhizo10 & 0 & 0 & $7 \%$ \\
\hline Prhizo11** & $33 \%$ & $25 \%$ & $12 \%$ \\
\hline Prhizo12** & $45 \%$ & $34 \%$ & 0 \\
\hline Prhizo13 & 0 & 0 & 0 \\
\hline Prhizo14 & 0 & $15 \%$ & $15 \%$ \\
\hline Prhizo15 & $5 \%$ & $5 \%$ & $10 \%$ \\
\hline Prhizo16 & 0 & $4 \%$ & 0 \\
\hline Prhizo17 & $5 \%$ & 0 & $5 \%$ \\
\hline \multicolumn{4}{|l|}{ Root } \\
\hline Proot 18 & 0 & $5 \%$ & $5 \%$ \\
\hline Proot 19 & $10 \%$ & $10 \%$ & $5 \%$ \\
\hline Proot 20 & 0 & $10 \%$ & $10 \%$ \\
\hline Proot 21 & $15 \%$ & $5 \%$ & $5 \%$ \\
\hline Proot 22 & 0 & 0 & 0 \\
\hline Proot 23 & $15 \%$ & $10 \%$ & 0 \\
\hline Proot 24 & $5 \%$ & $5 \%$ & $15 \%$ \\
\hline Proot 25 & $10 \%$ & $5 \%$ & $9 \%$ \\
\hline Proot 26 & 0 & 0 & 0 \\
\hline Proot 27 & $6 \%$ & $15 \%$ & $10 \%$ \\
\hline Proot 28 & $15 \%$ & 0 & $10 \%$ \\
\hline Proot 29 & $5 \%$ & $5 \%$ & 0 \\
\hline Proot 30 & $5 \%$ & 0 & $5 \%$ \\
\hline
\end{tabular}




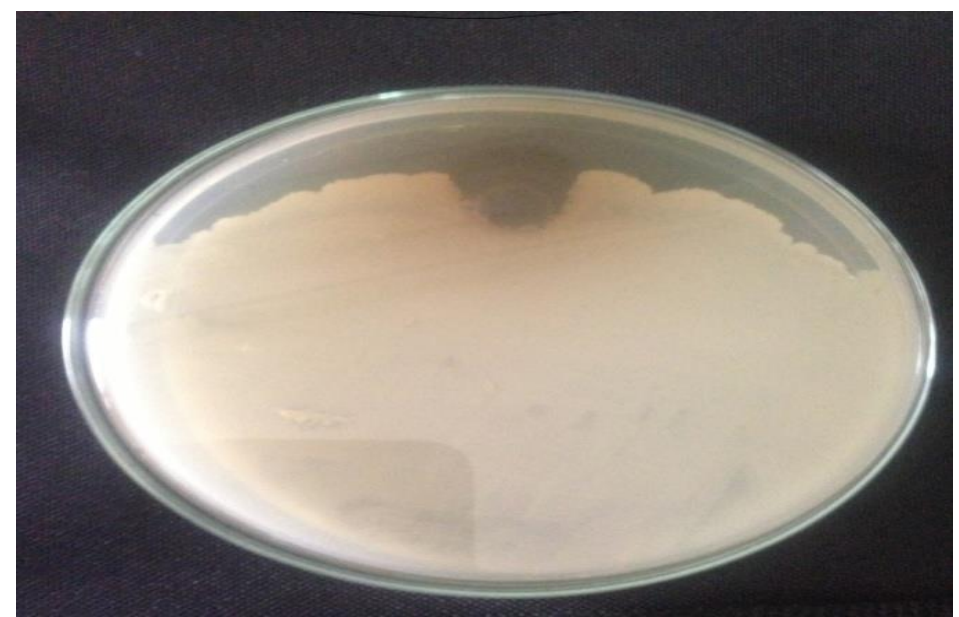

(A)

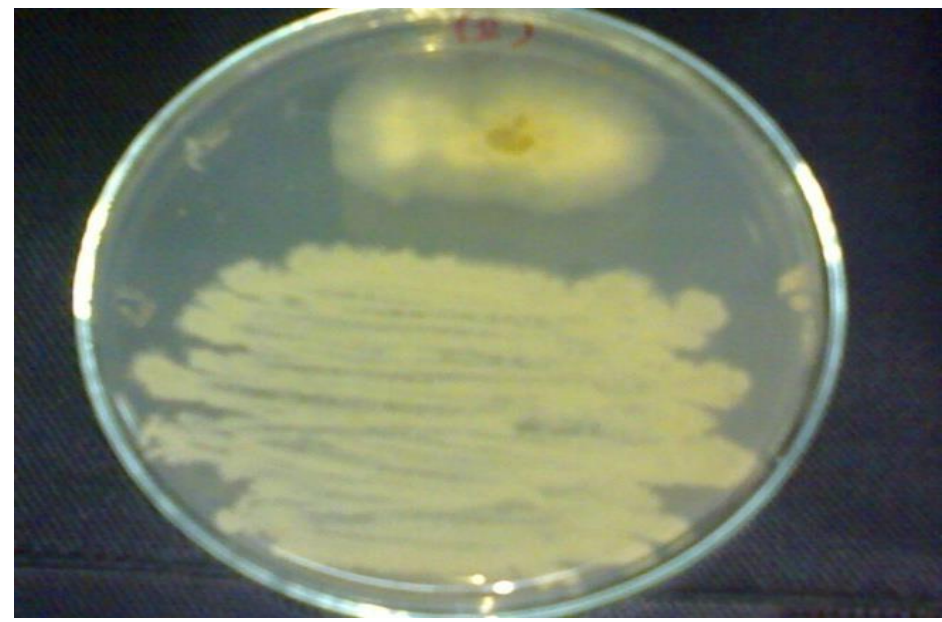

Fig. (1): Illustrated the antagonistic effect, (A) Brevundimonus diminuta KT277492 against F. solani. (B) Bacillus cereus KU058893 against $R$. solani.

\section{Screening of bacterial isolates for indole acetic acid (IAA) production}

All the isolates were screened for their ability to produce IAA. Data recorded in Table (3) revealed that only ten isolates with a percentage $33.3 \%$ of the isolates were able to produce IAA in the absence of tryptophan while $66.7 \%$ were unable to produce IAA in the absence of tryptophan. While only 13 isolate with percentage $43.33 \%$ were only able to produce IAA in the presence of tryptophan. In the absence of tryptophan, $B$. diminuta was the most active producer strain of IAA and it produced $24.912 \pm 0.045 \mu \mathrm{g} / \mathrm{ml}$. while B. cereusproduced $15.034 \pm 0.0707 \mu \mathrm{g} / \mathrm{ml}$ and the minimum production was $0.94 \pm 0.064 \mu \mathrm{g} / \mathrm{ml}$ by Proot 29 . While in the presence of tryptophan at $0.1 \%$ concentration, $B$. diminuta was also the most active producer of IAA and it produced $31.723 \pm 0.0059 \mu \mathrm{g} / \mathrm{ml}$. while $B$. cereus produced $22.2 \pm 0.046 \mu \mathrm{g} / \mathrm{ml}$. and the minimum IAA production was by Prhizo13and it was $0.032 \pm 0.043 \mu \mathrm{g} / \mathrm{ml}$ as in Table (3). The amount of IAA produced by $B$. diminuta is less than that have been reported by (Edi, 2003) which was $33.82 \mu \mathrm{g} / \mathrm{ml}$. while it was higher than that reported by De Freitas et al. (1997) which was $9.43 \mu \mathrm{g} / \mathrm{ml}$. on the other hand these results was similar to that produced by (UmaMaheswari et al., 2013) isolated twenty five bacterial isolates and found thatall the bacterial isolates produced higher amount of IAA in the presence of tryptophan. The IAA production ranged from $1.06 \mu \mathrm{g} \mathrm{ml}^{-1}$ to $6.46 \mu \mathrm{g} \mathrm{ml}^{-1}$ (with tryptophan presence) and in the absence of tryptophan $0.03 \mu \mathrm{g} \mathrm{ml} \mathrm{m}^{-1}$ to $0.12 \mu \mathrm{g} \mathrm{ml}^{-1}$. They added In the presence of tryptophan, the tow bacterial isolates RS10 and BS25 produced the maximum amount of IAA production was $\left(6.46 \mu \mathrm{g} \mathrm{ml}^{-1}\right)$ while in the absence of tryptophan the isolate BS22 produced the maximum amount of IAA which was $\left(0.12 \mu \mathrm{gml}^{-1}\right)$. 
Table (3): production of Indole Acetic Acid (IAA) by the bacterial strains in

the absence and presence of tryptophan

\begin{tabular}{|c|c|c|}
\hline Bacterial isolate no. & $\begin{array}{l}\text { Tryptophan 0\% } \\
\text { IAA }(\mu \mathrm{g} / \mathrm{ml})\end{array}$ & $\begin{array}{c}\text { Tryptophan } 0.1 \% \\
\text { IAA ( } \mu \mathrm{g} / \mathrm{ml})\end{array}$ \\
\hline Prhizo1 & $24.912 \pm 0.045$ & $31.723 \pm 0.0059$ \\
\hline Prhizo2 & $15.034 \pm 0.0707$ & $22.2 \pm 0.046$ \\
\hline Prhizo3 & ND & $10.45 \pm 0.0096$ \\
\hline Prhizo4 & ND & ND \\
\hline Prhizo5 & ND & ND \\
\hline Prhizo6 & $9.753 \pm 0.0093$ & $11.65 \pm 0.016$ \\
\hline Prhizo7 & ND & ND \\
\hline Prhizo8 & ND & ND \\
\hline Prhizo9 & ND & $0.85 \pm 0.0266$ \\
\hline Prhizo10 & ND & ND \\
\hline Prhizo11 & $12.26 \pm 0.043$ & $9.89 \pm 0.0246$ \\
\hline Prhizo12 & ND & ND \\
\hline Prhizo13 & ND & $0.032 \pm 0.043$ \\
\hline Prhizo14 & ND & ND \\
\hline Prhizo15 & $14.659 \pm 0.012$ & $15.821 \pm 0.126$ \\
\hline Prhizo16 & ND & ND \\
\hline Prhizo17 & ND & ND \\
\hline Proot 18 & $3.312 \pm 0.0061$ & $4.756 \pm 0.237$ \\
\hline Proot 19 & ND & ND \\
\hline Proot 20 & $0.568 \pm 0.022$ & $0.845 \pm 0.0655$ \\
\hline Proot 21 & $10.11 \pm 0.032$ & $10.39 \pm 0.453$ \\
\hline Proot 22 & ND & ND \\
\hline Proot 23 & $18.756 \pm 0.017$ & $20.991 \pm 0.022$ \\
\hline Proot 24 & ND & ND \\
\hline Proot 25 & ND & ND \\
\hline Proot 26 & ND & ND \\
\hline Proot 27 & ND & 0.15 \\
\hline Proot 28 & ND & ND \\
\hline Proot 29 & $0.94 \pm 0.064$ & $1.71 \pm 0.002$ \\
\hline Proot 30 & ND & ND \\
\hline
\end{tabular}

ND: the IAA production is not detected

\section{Production of Ammonia}

The data showed in Table (4) revealed that twenty four bacterial isolate with percentage $80 \%$ of the bacterial isolates were able to produce ammonia, while 6 isolates represented 20\% didn't produce ammonia. Almost 5 isolates which is equal to $16.6 \%$ of the isolate produced dark brown colour (+++) as shown in fig, while 12 bacterial isolates with percentage $40 \%$ showed deep yellow $(++)$, also 7 isolates with percentage $23 \%$ produced faint yellow (+) as shown in table (3). While as illustrated in table (4) B. diminuta and B. cereus produced dark brown color (+++) which indicate high yield production of ammonia. Sajani and Muthukkaruppan (2011) studied eight bacterial species; Bacillus spp., Pseudomonas spp, Azotobacter spp, Azospirillium spp, Phosphobacteria spp., Glucanoacetobacter spp. and peanobacillus spp., 100\% of them were able to produce ammonia.

\section{Production of HCN and siderphore}

The data recorded in Table (4) showed that about twenty bacterial isolates with percentage $90 \%$ of the isolates produced $\mathrm{HCN}$ ranging from dark brown (++++) to faint brown (+). Only one isolate $B$. cereus were able to produce dark brown (++++) which indicated that it produced high amount of $\mathrm{HCN}$ and $B$. diminuta gave brown colour which indicate moderate production of $\mathrm{HCN}$. while 8 isolates represent $26.67 \%$ were able to produce moderate amount of $\mathrm{HCN}$ and 7 isolates with $23.33 \%$ produce sufficient amount of $\mathrm{HCN}$ and 11 isolates represent $36.67 \%$ produced small amount of HCN. Fig. (2) Showed production of HCN by bacterial isolate $B$. diminuta and $B$. cereus compared with control. Ruchi et al., (2012) studied proved that almost all the eight isolates of pseudomonas sp produce $\mathrm{HCN}$ with (++++) while the other nineteen isolates showed production of $\mathrm{HCN}$ ranging between $(++)$ to $(+++)$. The data recorded in Table (4) revealed that Twenty isolates 
out of thirty with percentage $66.67 \%$ were found to be siderphore producers on the other hand $33.33 \%$ lack the ability to produce siderphore. While Ruchi et al., (2012) reported that twenty bacterial isolates represent $66.667 \%$ the bacterial isolates were found to be siderphore producers while 10 isolates with percentage 33.333\% didn't produce siderphore. Moreover Ladwal et al., (2012) studied five isolates, only two strains DKC2 and DKM5 were found to produce siderophore while the other three isolates were not able to produce siderophore.

\section{Phosphate solubilizing bacteria}

The data recorded in Table (4) showed that about eleven isolates were able to hydrolyze Phosphate which represents about $36.667 \%$ of the total isolates. While nineteen isolates were not able to hydrolysis phosphate with percentage $63.333 \%$. B. diminuta were able to hydrolysis phosphate with range (++++) and produce a large inhibition zone after one week but after thirty days it hydrolysis all the phosphate. While Bacillus cereus produced lesser inhibition zone than that is produced by $B$. diminuta. Fig (3) showed Phosphate solubilization by different bacterial isolates. Tilak et al. (2005) results confirm our results and stated that Pseudomonas and Bacillus are the main phosphate solubilizer bacteria.

Table (4): Screening of PGPR for multiple plant growth promoting activities: Ammonia $\mathrm{NH}_{4}, \mathrm{HCN}$, siderphore production and phosphate solubilization

\begin{tabular}{|c|c|c|c|c|}
\hline $\begin{array}{l}\text { Bacterial } \\
\text { isolate no. }\end{array}$ & $\begin{array}{l}\text { Ammonia } \\
\text { production }\end{array}$ & $\begin{array}{c}\mathrm{HCN} \\
\text { production }\end{array}$ & $\begin{array}{l}\text { Siderphore } \\
\text { production }\end{array}$ & $\begin{array}{l}\text { Phosphate } \\
\text { solubilization }\end{array}$ \\
\hline Prhizo1 & +++ & +++ & + & ++++ \\
\hline Prhizo2 & +++ & ++++ & + & +++ \\
\hline Prhizo3 & ++ & +++ & + & ND \\
\hline Prhizo4 & + & ++ & ND & ND \\
\hline Prhizo5 & ++ & ND & ND & ND \\
\hline Prhizo6 & ND & ++ & + & +++ \\
\hline Prhizo7 & ++ & + & ND & ND \\
\hline Prhizo8 & ++ & ++ & + & ND \\
\hline Prhizo9 & ND & + & ND & ND \\
\hline Prhizo10 & ND & + & + & + \\
\hline Prhizo11 & ++ & +++ & + & ND \\
\hline Prhizo12 & + & ND & + & + \\
\hline Prhizo13 & ++ & + & + & ND \\
\hline Prhizo14 & ND & + & ND & ND \\
\hline Prhizo15 & +++ & +++ & + & + \\
\hline Prhizo16 & ++ & + & + & ND \\
\hline Prhizo17 & ND & + & + & ND \\
\hline Proot 18 & +++ & +++ & ND & + \\
\hline Proot 19 & + & ++ & + & ND \\
\hline Proot 20 & ++ & ++ & ND & ND \\
\hline Proot 21 & + & +++ & ND & + \\
\hline Proot 22 & ND & ND & + & ND \\
\hline Proot 23 & ++ & +++ & + & ND \\
\hline Proot 24 & + & + & + & + \\
\hline Proot 25 & + & + & + & ND \\
\hline Proot 26 & ++ & + & + & ND \\
\hline Proot 27 & ++ & ++ & + & + \\
\hline Proot 28 & ++ & ++ & ND & ND \\
\hline Proot 29 & +++ & +++ & + & + \\
\hline Proot 30 & + & + & ND & ND \\
\hline
\end{tabular}




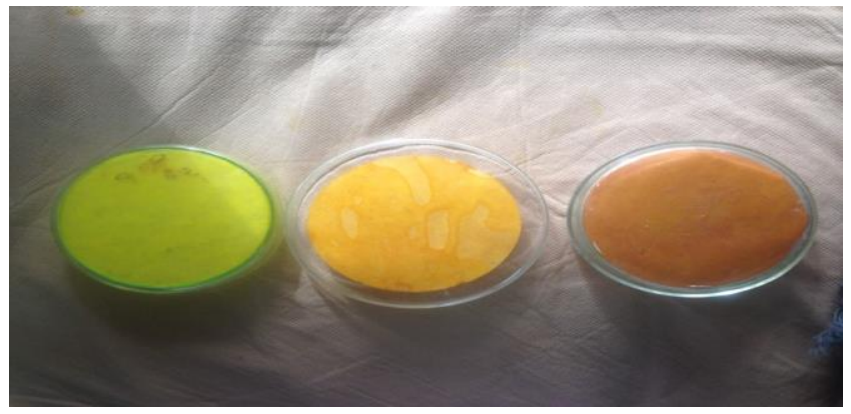

Fig (2) Production of HCN by bacterial isolate B. diminuta (Prhizo 1) with strength (+++) and B. cereus (Prhizo 2) with strength (++++)
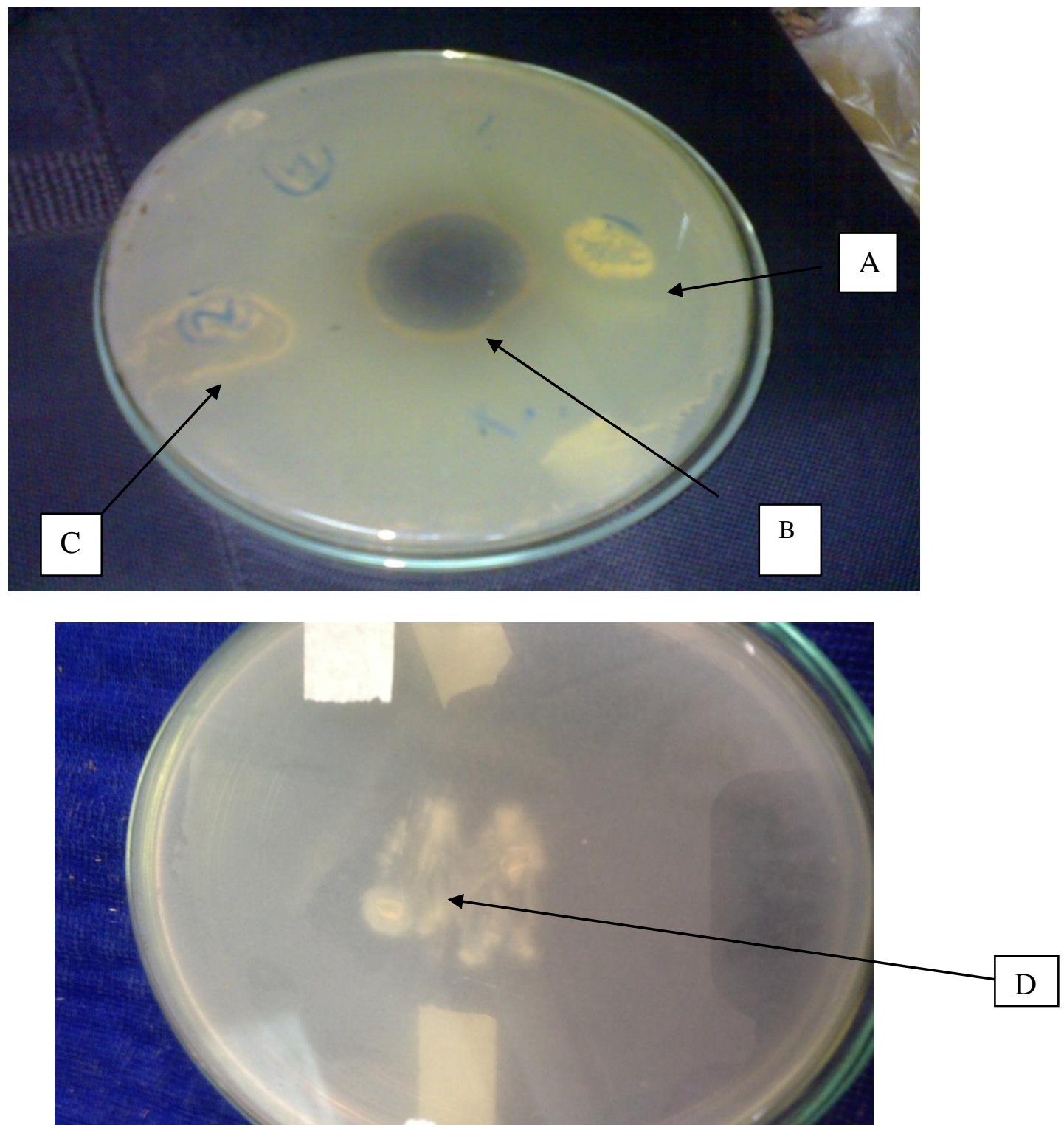

Fig (3) Phosphate solubilization by different bacterial isolates, A-Prhizo17 , B- B. cereus , C- Prhizo15, D- B. diminuta.

\section{Chitinase enzyme activity}

From all previous data, B. diminuta KT277492 and B. cereus KU058893 were most active plant growth promoting rhizobactria. They were screened for chitinase enzyme production using different media. The result in Table (5) showed that the bacterial isolate B. diminuta KT277492 showed the highest chitinase enzyme 
activity $95 \mathrm{IUL}^{-1}$ on the (NB+ chitin) medium that will be further studied for the optimization of medium components in the coming work. Chitinase production was reported in different species of Bacillus such as $B$. amyloliquefaciens, B. cereus, B. subtilis and B. megaterium (Wang et al., 2002 and Wang et al., 2006).

Table (5): Screening of different media for chitinase enzyme production by B. diminuta KT277492 and B. cereus KU058893.

\begin{tabular}{|c|c|c|}
\hline \multirow{2}{*}{ Media } & \multicolumn{2}{|c|}{${\text { Chitinase activity } \text { IUL }^{-1}}^{-1}$} \\
\cline { 2 - 3 } & B. diminuta KT277492 cereus KU058893 \\
\hline LB & 70 & 0.0 \\
\hline KB & 20 & 32 \\
\hline NB & 79 & 39 \\
\hline WB & 65 & 0.0 \\
\hline (NB+chitin) & 95 & 54 \\
\hline
\end{tabular}

Lauri bertaini broth (LB), King broth (KB), Nutrient broth (NB), yeast extract (WB)

Molecular Identification of the most dominant bacterial isolates (Prhizo1 \&Prhizo 2).

The molecular identification using partial sequencing of $16 \mathrm{~S}$ rDNA with available NCBI GeneBank database was tested for the selected isolates Prhizo 1 and Prhizo2. The nucleotide sequence of bacterial isolates were submitted to the GenBank and deposited in the GeneBank under the accession numbers (KT277492 and KU058893, respectively). Results obtained from alignments showed that Brevundimonas diminuta KT277492 (Prhizo1) revealed high identity (98\%) to Brevundimonas diminuta strain NBRC 12697 (GeneBank accession number NR113602) and revealed high close similarity (98\%) with species Brevundimonas diminuta JCM2788 (GeneBank accession number NR113238).

Also the alignment results showed that Bacillus cereusKU058893 (Prhizo2) revealed high identity (95\%) to Bacillus cereus strain MVSV4 (GeneBank accession number JN089708) and show high similarity $94 \%$ with species Bacillus cereusB64 with (GeneBank accession number HM588150).

The phylogenetic trees of the bacterial isolates were displayed using the TREEVIEW Program that showed the sequences of close relatives obtained from GenBank to resolve the phylogenetic relations with ancestor. Fig. (4 and 5)

Mahwish et al., (2013) reported that Bacillus and Pseudomonas have been found to be as themostdominantgenera isolates in various plant research (Hallmann and Berg, 2006).

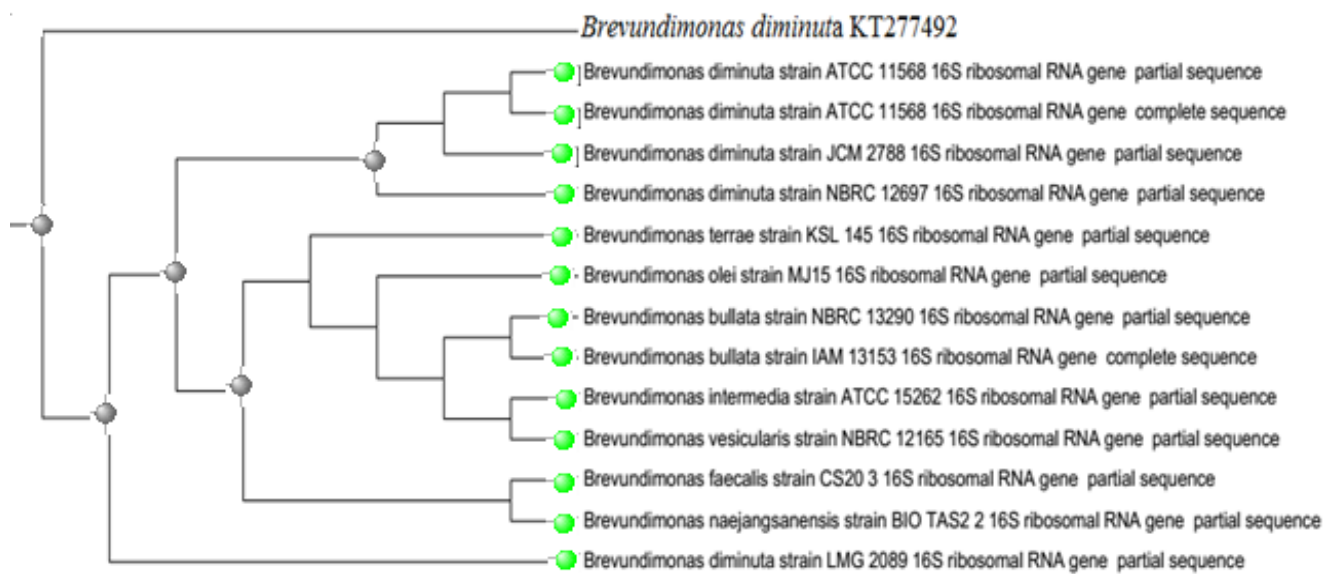

Fig. (4):The phylogenetic tree based on partial sequencing of $16 \mathrm{~S}$ rDNA gene showing relationship neighbor-joining between the bacterial isolate Brevundimonas diminuta KT277492 and other closely related sequences on NCBI GeneBank reference taxa. 


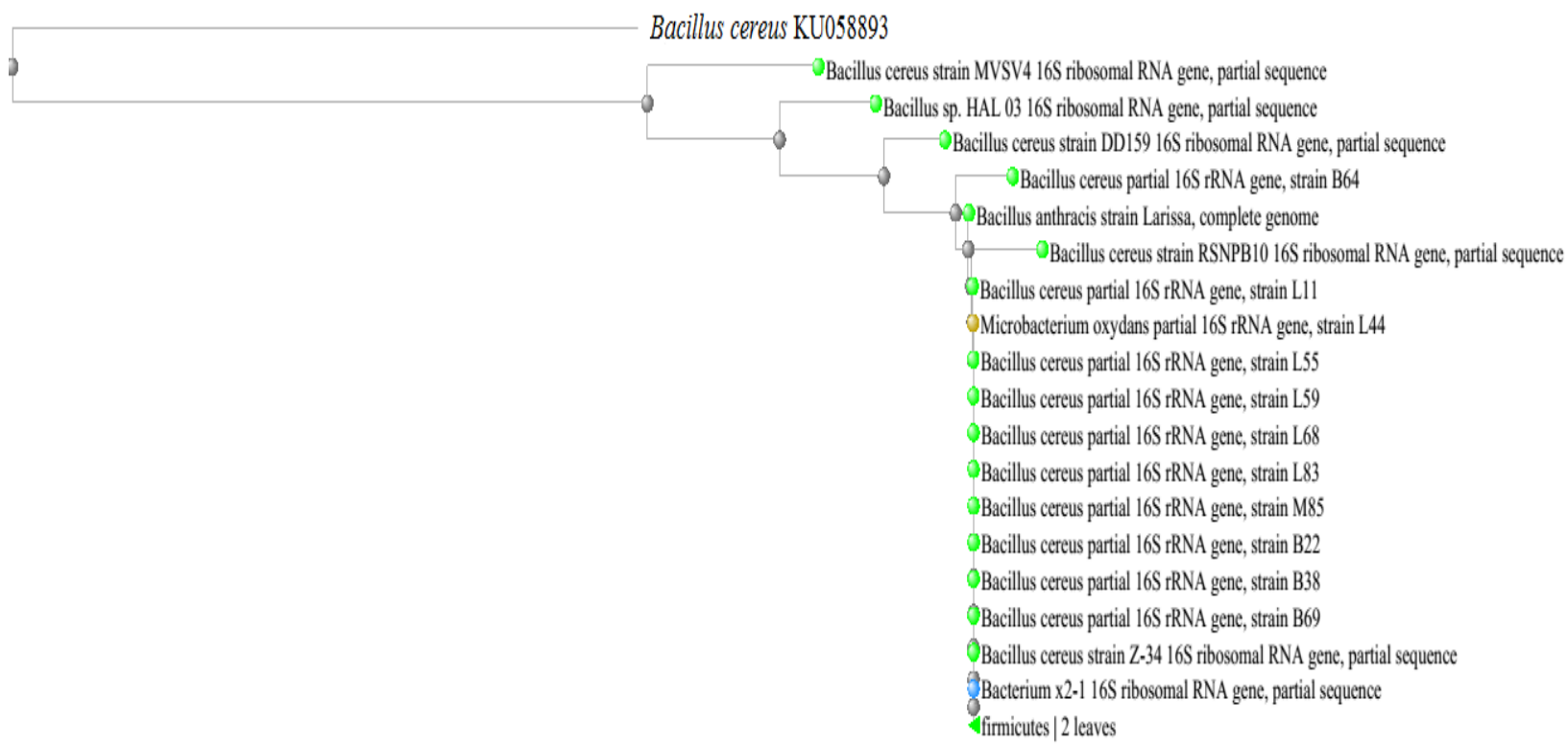

Fig. (5): The phylogenetic tree based on partial sequencing of 16S rDNA gene showing relationship neighbor-joining between the bacterial isolate Bacillus cereus KU058893 and other closely related sequences on NCBI GeneBank reference taxa

\section{CONCLUSION}

The ability of rhizobacteria to produce phytohormones differs from bacterial strain to another and may be essential in suppression of pathogenic fungi. Our study conclude that the bacterial isolates Prhizo 1 and Prhizo 2 genetically identified as Brevundimonus diminuta KT277492 and and Bacillus cereus KU058893. They are the most active plant growth promoting rhizobactria which have the ability to produce different types of phytohormones as well as good chitinase enzyme activity and suppress various pathogenic fungi with variable degree.

\section{ACKNOWLEDGEMENT}

This work was supported by Chemistry of Natural and Microbial products Department, National Research Centre (NRC) Giza, Egypt.

\section{REFERENCES}

[1] Abou-Zeid, A.M.; Altalhi, A.D. and Abd El-Fattah, R.I. (2008).Fungal Control of Pathogenic Fungi Isolated From Some Wild Plants in Taif Governorate,Saudi Arabia Mal. J. Microbiol., 4(1):30-39.

[2] Abou-Zeid, A.M.; Mahmoud, Y.A.G. and Talhi, A.E. (2004). Effect of gaucho insecticide on the efficacy offungicides used to control root-rot and damping off diseasesin cotton seedlings. Egypt. J. of Microbiol.; 9:1-10.

[3] Anjum, M.A.; Sajjad, M.R.; et al (2007). Response of cotton to plant growth promoting rhizobacteria (PGPR) inoculation under different levels of nitrogen. Journal of agricultural research 45, 2, 135:143.

[4] Ashrafuzzaman, M.; Hossen, F.A.; Razi, I. M.; Hoque, M.A.; Shahidullah, S.M. and Meon, S. (2009). Efficiency of plant growth-promoting rhizobacteria (PGPR)for the enhancement of rice growth. Afr J Biotechnol 8:1247-1252.

[5] Bakker, A. W. and Schipperes, B. (1987). Microbial cyanide production in the rhizosphere in relation to potato yield reduction and Pseudomoasspp. - mediated plant growth stimulation Soil Biol. Biochem. 19: $451-457$.

[6] Beneduzi, A.; et al. (2012). Plant growth-promoting rhizobacteria (PGPR): Their potential as antagonists and biocontrol agents. Genetics and Molecular Biology, 35, 4 (suppl), 1044-1051.

[7] Bouziane, Z.; Dehimat, L.; Abdel azia, W.; Benabdelkader, M. and Kacem chaouch, N.(2011). The antagonism between Trichoderma virdi and other pathogenic fungal strains in Zea Mays. Agricultural and biology journal of north America. 2:4, 584- 590. 
[8] Budi, S.W. and Nunang, L. M.; (2012). Bacteria from arbuscular from mycorrhizal fungis pores Gigaspora sp. and Gigaspora Glomussp. Their antagonistic effects towards soil borne fungal pathogens and growth stimulation ofGigaspora sp. In vitro .Biotropia; 20: $38-49$

[9] Cappuccino, J.G. and Sherman, N. (1992). Biochemical activities of microorganisms. In: Microbiology, ALaboratory Manual. The Benjamin / Cummings Publishing Co. California, USA.

[10] Datta, M.; Rakhi, P.; Chandan, S.; Manas, K. P. and Samiran, B. (2011). Plant growth promoting rhizobacteria enhance growth and yield of chilli (Capsicum annuumL.) under field conditions. AJCS 5(5):531-536.

[11] Davis, P.J. (1995). Plant hormones: physiology, biochemistry and molecular biology. Kluwer academic publishers, Netherland.

[12] De Freitas, J. R.; Banerjee, M.R. and Germida, J.J. (1997). Phosphate solubilizing rhizobacteria enhance the growth and the yield but not phosphorus uptake of canola (Brassica napus L.). Biol. Fertil. Soils 24:358- 364.

[13] Dobbelaere, S.; Vanderleyden, J. and Okon, Y. (2003) .Plant growth promoting

[14] Edi, H. (2003). Screening of soil bacteria for plant growth promotion activities in vitro. Indonesian journal of agricultural science 4 (1) 27-31.

a. $\quad$ Effects of diazotrophs in the rhizosphere. CRC Crit Rev Plant Sci 22:107-149.

[15] Gardner, J.M.; A.W. Feldman and Zablatowicz, R.M. (1982). Identity and behaviour of xylem-residing bacteria in rough lemon roots of Florida citrus trees. Appl. Environ. Microbiol. 43: 1335-1342.

[16] Geetha, K.; enkatesham, E.V.; Hindumathi, A. and hadraiah, B.B. (2014). solation, screening and characterization of plant growth promoting bacteria and their effect on VignaRadita(L.) R.Wilczek. Int.J.Curr.Microbiol. App.Sci 3(6) 799-809.

[17] Glick BR. The enhancement of plant growth by free-living bacteria. Can J Microbiol 1995;41:109-117.

[18] Gordon, S. A. and Weber, R. P. (1951). Colorimetric estimation of indole acetic acid. Plant Physiol. 26:192-195.

[19] Gray, E.J. and Smith, D.L. (2005). Intracellular and extracellular PGPR: Commonalities and distinctions in the plant-bacterium signaling processes. Soil BiolBiochem 37:395-412.

[20] Hallmann J, and Berg G. (2006). "Spectrum and population dynamics of bacterial root endophytes, "in Microbial Root Endophytes, eds B. Schulz, C. Boyle, and T. Sieber (Heidelberg: Springer), 15-31.

[21] Hamed, E. R.;Hassan M. A.; Ghazi, E.A. El-Gamal, N.G. and Shehata, H. S. (2015). Trichoderma asperellum isolated from salinity soil using rice waste as biocontrol agent for cowpea plant pathogens straw. Journal of Applied Pharmaceutical Science .5 (2), 091-098,

[22] Higgins, K. L., Arnold, A. E., Miadlikowska, J., Sarvate, S. D., and Lutzoni, F.,(2007).Phylogenetic relationships, host affinity, and geographic structure of boreal and arcticendophytes from three major plant lineages. Molecular Phylogenetics and Evolution42, 543-555.

[23] Kabir, L.; Sang, W. K.; Yun, S. K.andYoun , S.L. (2012). Application of rhizobacteria for plant growth promotion effect and biocontrol of anthracnose caused by Colletotrichumacutatumon pepper. Mycobiology 40(4): 244-251.

[24] Kaushal, M.; Kaushal, R.; Thakur, B. S. and Spehia, R. S. (2011). Effect of plant growth-promoting rhizobacteria at varying levels of $\mathrm{N}$ and $\mathrm{P}$ fertilizers on growth and yield of cauliflower in mid hills of Himachal Pradesh. Journal of Farm Sciences 1(1) : 19-26.

[25] Khan, M. S. (2006). Screening of free-living rhizospheric bacteria for their multiple plant growth promoting activities. 163:173-181.

[26] Kloepper, J.W.; Lifshitz, R. and Zablotowicz, R.M. (1989). Free-living bacterial inocula for enhancing crop productity. Trends Biotechnol 7:39-43.

[27] Kloepper, J.W.; Schoth, M.N and Miller, T.D. (1980). Effects of rhizosphere colonization by plant growth- promoting rhizobacteria on potato plant development and yield. Phytopathol. 70:1078-1082.

[28] Kuddus, S.M. and Ahmad, R.I.Z. (2013). Isolation of novel chitinolytic bacteria and production optimization of extracellular chitinase. Journal of genetic engeneering \& biotechnology 11:39-46.

[29] Kumar, A.; Amit, K.; Shikha, D.; Sandip, P.; Chandani, P. and Sushila, N. (2012). Isolation, screening and characterization of bacteria from Rhizospheric soils for different plant growth promotion (PGP) activities: an in vitro study. Recent Research in Science and Technology, 4(1): 01-05.

[30] Kushwah, A. A. ; Baily, S. B.;Maxton, A. and Ram, G. D. (2013). Isolation and characterization of PGPR associated with cauliflower roots and its effect on plant growth. The biascan 8(1): 95-99.

[31] Ladwal, A.; Divya, B. and Deepak, K. M. (2012). Effect of coinoculation of Mesorhizobiumcicerwith PGPR on Cicer arietinum. Australian Journal of Basic and Applied Sciences, 6(9): 183-187 
[32] Loper, J. E. and Schroth, M. N. (1986). Influence of bacterial sources of indole- 2-acetic acid on root elongation of sugar beet. Phytopath. 76:386-389.

[33] Lwin, M. K.; Moe, M. M.; Tar, T. and Aung, W.Z.M. (2012). Isolation of plant hormones (indole-3acetic acid- IAA) producing rhizobacteria and study on their effects on maize seedling. Engineering journal vol. 16 issue 5

[34] Mahwish, Z.M.; Kaleem, A.; Sohai, I. H. and Nasir, R. (2015). Isolation and identification of indigenous plant growth promoting rhizobacteria from Himalayan region of Kashmir and their effect on improving growth and nutrient contents of maize (ZeamaysL.). Front. Microbiol. 6:207. 10.338.

[35] Miller, G.L. (1959). Use of dinitrosalicylic acid reagent for determination of reducing sugars. Anal Chem, 31, 426-8,

[36] Nelson, L. M. (2004). Plant growth promoting rhizobacteria (PGPR): Prospect for new inoculants. Crop Management doi: 10. 1094/CM-2004-0301-05-RV.

[37] Roberts, W.K. and Selitrennikoff, C.P. (1988). Plant and bacterial

a. chitinases differ in antifungal activity. J. Gen.Microbiol.;

b. 134:169-176.

[38] Ruci, R.; Ritica,K.; Ajay, K.; Amit, K.; Sandip, P.; Shobit, T. and Mohinder, k. (2012). Evaluation of plant growth promoting attributes and lytic enzymes production by fluorescent pseudomonas diversity associated with apple and pear. International journal of scientific and research publications. 2(2) - 1:8.

[39] Sajani S. and Muthukkaruppan SM. Characterization of plant growth promoting rhizobacteria and fungi associated with rice, mangrove and effluent contaminated soil. Curr. Bot. 2011;2(3): 22-25.

[40] Salamone, I. E. G. (2000). Direct beneficial effects of cytokinin producing rhizobacteria on plant growth. Ph.D. Thesis, University of Saskatchewan, Saskatoon, SK, Canada; 128.

[41] Shehata H S, and E. Eleiwa M. (2012). Potential for Improving Healthy and Productivity of Soybean by Plant Growth Promoting Rhizobacteria. Australian Journal of Basic and Applied Sciences, 6(4): 98-107.

[42] Sri, W. B. and Nunang, L. M. (2013). Bacteria from arbuscular mycorrhizal fungi spores sp. and antagonistic effects towards soilborne fungal pathogens and growth stimulations of spp. Gigaspora Glomus Gigaspora in vitro. Biotropia, $20,1,: 38-49$.

[43] Sudhakar, P. and Nagarajan, P. (2011). Production of chitinase by solid state fermentation from Serratia marcescens. International Journal of ChemTech Research 3 (2):590-598.

[44] Sujatha, N. and Ammani, K. (2013).Siderphore production by the isolates of fluorescent pseudomonads. IJGRR, volume 5 issue 20.

[45] Tilak KVBR, Ranganayaki, N., Pal, K. K.; et al (2005). Diversity of plant growth and soil health supporting bacteria. Curr. Sci.89: 136-150.

[46] UmaMaheswari,T. ; Anbukkarasi, K.; Hemalatha, T. and Chendrayan, K. (2013). Studies on phytohormone producing ability of indigenous endophytic bacteria isolated from tropical legume crops. Int.J.Curr.Microbiol.App.Sci, 2(6): 127-136.

[47] Varese, G.C.; Portinaro, S.; Trotta, A.; Scannerini, S.; Luppi-Mosca, A.M.; Martinotti, M.A. (1996). Bacteria associated with sporocarps and ectomycorrhizae and their effects on in vitro growth of the mycobion. Symbiosis; 21: 129-47.

[48] Ulhoa, C.J. and Peberdy, J.F. (1991). Regulation of chitinase synthesis in Serratia marcescens. J Gen Microbiol, 14: 2163-9.

[49] Vessey, J. K. (2003). Plant growth promoting rhizobacteria as biofertilizers. Plant Soil 255: 571-586.

[50] Vincent, J. M. (1970). A manual for the practical study of the root nodule bacteria. Blackwell Scientific publications Oxford and Edinburgh. pp. 1-3.

[51] Wang, S.L., I.L. Shih, W.W. Liang and C.H. Wang, (2002). Purification and characterization of two antifungal chitinases extracellularly produced by Bacillus amyloliquefaciens V656 in a shrimp and crab shell powder medium. J. Agric. Food Chem., 50: 2241-2248.

[52] Wang, S.L., T.Y. Lin, Y.H. Yen, H.F. Liao and Y.J. Chen (2006). Bioconversion of shellfish chitin wastes for the production of Bacillus subtilis W- 118 chitinase. Carbohydr. Res., 341: 2507-2515.

[53] Weisburg, W. G., Barns, S. M., Pelletier, D. A., Lane, D. J., (1991). 16S ribosomal DNA amplification for phylogenetic study. Journal of Bacteriology 173, 697-703.

[54] Zinniel, D.K.; P. Lambercht; N. Beth Harris, Z.; Feng, D.; Kuczmarski, P.; Highley, C.A.; Ishimaru, A.; Arunakumari, R.G.; Barletta, A. and Vidaver, A.K. (2002). Isolation and characterization of endophytic colonizing bacteria from agronomic crops and prairie plants. Appl. Environ. Microbiol. 68:2198-2208. 